УДК 330.34:656.2

DOI: https://doi.org/10.37320/2415-3583/10.10

Обруч Г.В.

кандидат економічних наук, докторант, Украӥнський державний університет залізничного транспорту ORCID: https://orcid.org/0000-0002-9082-2344

\title{
РОЗВИТОК ПОСЛУГ ПІДПРИЕМСТВ ЗАЛІЗНИЧНОГО ТРАНСПОРТУ НА ОСНОВІ РОЗБУДОВИ ЦИФРОВИХ ПЛАТФОРМ
}

\begin{abstract}
У статті визначено, щео підвищення конкурентоспроможності $і$ забезпечення збалансованого розвитку підприємств залізничного транспорту потребує всебічного вдосконалення процесів реалізації їхніх послуг. Акцентовано увагу на невідповідності послуг підприємств залізничного транспорту критеріям збалансованого розвитку за показниками технічного стану, надійності та безпеки, логістичної ефективності, ресурсозбереження та клієнторієнтованості. Зроблено висновок, щзо ичфрровізація стає рушійним чинником розвитку послуг підприємств залізничного транспорту, де ключовим інструментом виступає формування цифрових платформ як комунікаційного майданчика і технології реалізації послуг. Визначено переваги, функиії, принципи та організаційні умови для створення циифрових платформ підприємств залізничного транспорту.
\end{abstract}

Ключові слова: розвиток, послуги, підприємства залізничного транспорту, ичифровізація, ијифрова платформа.

Постановка проблеми. Забезпечення збалансованого розвитку підприємств залізничного транспорту вимагає вдосконалення системи транспортного обслуговування як шляхом модернізації технологічного процесу перевезення, так і через поліпшення сервісу. Серйозного переосмислення потребує організація взаємовідносин підприємств залізничного транспорту з клієнтами. Багаторічне пристосування клієнтів до технологічних можливостей перевізників поряд із багатоланковістю системи надання послуг зумовлює й нині значні непродуктивні витрати часу, сил і засобів клієнтів. Нерозвиненість необхідних клієнтам комплексних транспортних послуг і недостатній їх рівень, відсутність системи отримання інформації про послуги знижують конкурентоспроможність та ефективність функціонування підприємств залізничного транспорту.

Аналіз останніх досліджень і публікацій. Питання збалансованого розвитку підприємств залізничного транспорту в умовах цифрової трансформації економіки розкривається в працях таких учених, як: В.Л. Дикань, М.В. Корінь [1], В.В. Компанієць [2], В.О. Овчиннікова, В.І. Торопова [3], І.В. Токмакова, О.Ю. Чередниченко, I.M. Войтов, Я.С. Паламарчук [4] та ін.

Поряд із цим стрімкий розвиток науково-технічного прогресу та цифрова трансформація суспільства зумовлюють підвищення вимог споживачів до транспортних послуг підприємств залізничного транспорту. У зв'язку із цим потребує подальшого дослідження проблематика розвитку послуг на підприємствах залізничного транспорту на основі цифрових технологій.

Мета статті полягає у розкритті ролі цифрових платформ у розвитку послуг підприємств залізничного транспорту, визначенні їхніх переваг, функцій принципів та організаційних умов розбудови.
Виклад основного матеріалу. Розвиток послуг залізничного транспорту є процесом їхніх кількісних, якісних та структурних змін, що відповідають комплексу макро-, мікро- та індивідуальних цілей зовнішніх та внутрішніх споживачів. Варто констатувати, що розвиток послуг залізничного транспорту відбувається під впливом сукупності чинників. До складу внутрішніх чинників слід віднести виробничі, економічні, соціальні, логістичні, інтелектуально-інформаційні, організаційно-управлінські, маркетингові та кадрові. Зовнішні чинники включають такі групи, як інституційні, економічні, соціальні, науково-технічні, інтеграційні та інформаційні.

В умовах сьогодення підприємства залізничного транспорту для забезпечення конкурентоспроможності мають проводити активну роботу в напрямі підвищення якості та поліпшення послуг. АТ «Укрзалізниця» у 2018 р. впроваджувалися заходи, спрямовані на утримання наявних та залучення нових клієнтів у галузі вантажних перевезень. Філією «Центр транспортної логістики» проводилися оптимізація вантажних перевезень, удосконалення системи надання транспортних послуг, поліпшення їхньої якості та залучення додаткових вантажопотоків. Зокрема, протягом 2018 р. філією укладено 5526 договорів та додаткових угод (серед них 145 договорів про організацію та проведення розрахунків за перевезення та 2868 - про надання послуг). До того ж було впроваджено такі заходи:

- організовано продаж послуг подобового використання вагонів власності АТ «Укрзалізниця» iз застосуванням «ProZorro. Продажі»;

- розроблено додатковий модуль до АС «КлієнтУЗ» щодо надання клієнтами АТ «Укрзалізниця» дозволів на використання кодів платника за їх договорами іншим відправникам й одержувачам та контролю застосування наданих кодів; 
- розроблено технологію розподілу критих вагонів засобами АС «Управління пересилкою порожніх вагонів» та впроваджено в експлуатацію надане програмне забезпечення;

- введено в експлуатацію актуальний Договір про надання послуг, який регулює взаємовідносини між АТ «Укрзалізниця» та клієнтами (перевагами укладання договору $\epsilon$ проведення розрахунків єдиним підрозділом - філією ЄРЦ, спрощення процедури договірних відносин, зведення до мінімуму кодів платників та особових рахунків) [5].

У сфері пасажирських перевезень сервіс придбання проїзних/перевізних документів через Інтернет користується все більшим попитом. Оформлення проїзду пасажир може здійснити через сайт онлайн-сервісу AT «Укрзалізниця» booking.uz.gov.ua та через мережу агентів. На сайті booking.uz.gov.ua забезпечено можливість оформлення проїзду з пересадкою (складний маршрут прямування). Через Інтернет можна придбати квитки на потяги сполученням Одеса - Пшемисль та Київ - Мінськ Вільнюс - Рига формування АТ «Укрзалізниця». Забезпечено можливість оформлення проїзних документів на регіональні поїзди. Контроль посадочних документів здійснюється засобами МТКД (мобільні термінали контролю документів) шляхом зчитування QR-коду [5].

Однак і нині клієнти та інші стейкхолдери підприємств залізничного транспорту відзначають невідповідність транспортних послуг критеріям збалансованого розвитку за показниками технічного стану, надійності та безпеки, логістичної ефективності, ресурсозбереження та клієнтоорієнтованості.

Під час вирішення даної проблеми необхідно звернути увагу на те, що неможливо забезпечити розвиток послуг, не створивши необхідні для цього умови, оскільки послуга є результатом різноманітних дій із боку суб'єктів, які беруть участь у їх наданні. Нові можливості в досягненні вищевказаних критеріїв розвитку послуг підприємств залізничного транспорту надають процеси цифровізації, фундаментом яких стало поширення мобільних пристроїв, підвищення доступу до високошвидкісного Інтернету, вдосконалення цифрових технологій (штучного інтелекту, обробки великих даних, Інтернету речей, технологій розподілених реєстрів, хмарних обчислень тощо). Нині цифровізація стає рушійним чинником розвитку послуг підприємств залізничного транспорту.

Глобальна цифровізація вже охопила залізниці багатьох країн, і Україні не можна відставати. Основними організаційними ідеями цифрової трансформації підприємств залізничного транспорту мають стати [6]: 1) вирівнювання цілей залізничної галузі - балансування об’єктів на рівні маршрутів мережі за допомогою операцій iз потягами (Train Operating) окремих компаній i трансграничними, національними і стратегічними цілями; 2) спільна робота в інтересах вигід клієнтів, яка об'єднує нові технології й операційні зміни в інтересах клієнтів залізниці; 3) створення впевненості в ланцюжку постачань - чітка карта маршруту і прихильність до реалізації цифрових технологій, що в сукупності дає змогу постачальникам і клієнтам планувати свою участь та ресурси; 4) вирішення проблеми нестачі необхідних навичок - визначення необхідних навичок і підготовка інженерів, операторів і супроводжуючих осіб із необхідним рівнем компетентності відповідно до програми реалізації; 5) розуміння переваг поступового створення ETCS, або готової цифрової залізниці, й отримання ранніх переваг шляхом поетапного розгортання компонентів цифрової залізниці (C-DAS/ATO/TM/ETCS).

Варто враховувати, що цифрова трансформація економіки прискорила поширення платформної моделі ведення бізнесу, де цифрова платформа - це складна інформаційна система, що забезпечує виконання функцій взаємозв'язку між учасниками ринку, вона відкрита для використання клієнтами і партнерами, включаючи розробників додатків, постачальників послуг і агентів [7].

Під цифровою платформою розуміють і віртуальний торговельний майданчик, і всю сукупність його користувачів, і програмний, апаратний та мережевий комплекси, бізнес-модель і підприємство, що іії реалізує. У поняття цифрової платформи входить як сама технологічна конструкція, так і платформні бізнес-модель і екосистема. Під час формування останньої виділяють чотири основних типи платформних акторів: власників платформи, менеджерів (провайдерів), комплементорів (розробників ядра і периферійних елементів цифрової платформи) і кінцевих незалежних користувачів (споживачів, постачальників та ін.).

Цифрові платформи є різновидом багатосторонніх платформ і являють собою гібридні структури, орієнтовані на створення цінності шляхом забезпечення прямої взаємодії і здійснення трансакцій між декількома групами сторонніх користувачів.

Багатостороння платформа - найпрогресивніша і перспективна форма існування бізнесу, оскільки вона являє собою модель вільного ринку. Така платформа дає змогу економічним агентам активно використовувати можливості, що формуються в рамках цифрової економіки. Вони підвищують ефективність бізнес-процесів, забезпечують швидкі і надійні комунікації, створюють можливості для розвитку економіки спільного користування та формування нових способів створення вартості і механізмів взаємодії й обміну між економічними агентами, знижуючи при цьому роль географічних, часових та інших 
чинників, що впливають на соціально-економічні процеси, інститути і явища.

Розбудова на підприємствах залізничного транспорту багатосторонніх платформ дає їм змогу реалізовувати такі функції [7]:

- магніту, що залучає й утримує користувачів однієї або обох сторін;

- сторожа-охоронця біля входу на ринок (фільтра, що здійснює позитивний відбір, дотримується стандарту взаємодії високої якості);

- збирача, аналізатора та джерела ринкової інформації;

- звідника (мачмейкера) - дизайнера ринку

і творця сталого розподілу між сторонами;

- посередника-представника;

- гаранта-поручителя для однієї або обох сторін;

- інноваційної майстерні 3 інструментарієм для колаборації;

- лідера-інноватора, який задає, дотримується і поширює високі стандарти інновацій.

Беручи до уваги функції, які зможуть виконувати підприємства залізничного транспорту, перевагами формування цифрових платформ транспортних послуг підприємств залізничного транспорту $\epsilon$ :

- зниження ролі інституту традиційного посередництва i, відповідно, трансакційних, операційних, тимчасових та інших витрат;

- зниження вхідних бар'єрів на ринки транспортних послуг, окрім іншого, зростання індивідуального, малого та середнього підприємництва;

- розширення асортименту та підвищення якості послуг, у тому числі шляхом персоналізації та більш повного врахування інтересів і можливостей клієнтів;

- залучення в економічну діяльність невикористовуваних або недовикористовуваних активів;

- активізація консолідованого ресурсу (державного та підприємницького) через організацію комплексних проєктів економічного та технологічного розвитку, що забезпечує додаткові умови сталого режиму економічного відтворення;

- підвищення якості інформаційного обміну даними між учасниками ринку, що створює систему постійно працюючого зворотного зв'язку.

Для забезпечення ефективності цифрових платформ послуг підприємств залізничного транспорту їх формування має грунтуватися на таких принципах:

- повноти інформації, що визначає достатність інформації для прийняття рішення 3 управління локальними бізнес-процесами учасника перевізного процесу у вузлах взаємодії з іншими;

- актуальності - інформація має бути достовірною в реалізованій частині управлінських рішень учасників перевізного процесу, тобто в системі відсутня інформація про нереалізовані (майбутні) рішення учасників процесу;
- прогнозованості - на основі статистичних даних виконується прогноз очікуваного стану об'єкта або процесу в транспортно-логістичному ланцюзі;

- конкретності - система орієнтована для отримання інформації та управління окремими видами товарно-матеріальних потоків (вантажів), а не укрупненими товарними номенклатурами;

- обмеженості часу реакції - підключення до єдиної інформаційної системи повинно давати учасникам транспортно-логістичного процесу змогу приймати рішення, що знижують їхні витрати;

- цілісності - система функціонує за обов'язкового представлення інформації про всіх учасників транспортно-логістичних бізнес-процесів;

- інституціональності - нормативно-правове забезпечення організації перевезень спрямовано на обов'язкову «співпрацю» учасників транспортних процесів на базі єдиного інформаційного простору;

- безпеки, коли інформація, представлена в єдиному інформаційному просторі про бізнеспроцеси учасника транспортно-логістичного ланцюга, не може бути використана проти самого учасника за винятком інтересів кінцевого споживача і ринку, тобто інформація не належить до сфери конфіденційної й є публічною для прийняття ефективних управлінських рішень іншими учасниками ринку.

Для успішної роботи цифрової платформи повинні бути виконані такі організаційні умови:

- розроблено список транспортних послуг, цінова політика на ці послуги та порядок розрахунків;

- розроблено цінову політику та порядок розрахунків за послуги;

- розроблено порядок роботи відвідувачів, у тому числі клієнти та партнери повинні обов'язково пройти процедуру реєстрації на майданчику та отримати відповідні засоби захисту;

- визначено і технічно реалізовано взаємодію інформаційних систем підрозділів підприємств залізничного транспорту.

Висновки. Таким чином, підвищення конкурентоспроможності і забезпечення збалансованого розвитку підприємств залізничного транспорту потребує всебічного вдосконалення процесів реалізації їхніх послуг. Вирішення даного завдання особливо актуальне у зв'язку 3 невідповідністю послуг підприємств залізничного транспорту критеріям збалансованого розвитку за показниками технічного стану, надійності та безпеки, логістичної ефективності, ресурсозбереження та клієнтоорієнтованості. Перспективним напрямом вирішення окресленої проблеми є розвиток послуг шляхом використання цифрового інструментарію, серед яких вагоме значення має розбудова цифрових платформ. Визначені функції та переваги цифрових платформ указують на доцільність 
реалізації даного інструментарію на підприємствах залізничного транспорту. Беручи до уваги сутнісно-змістовний контекст багатосторонньої цифрової платформи як моделі вільного ринку, подальші дослідження слід спрямувати на розроблення концептуальних засад організації взаємодії його агентів, що сприятиме досягненню економічної ефективності функціонування платформ.

\section{Список використаних джерел:}

1. Дикань В.Л., Корінь М.В. Розвиток високошвидкісного руху в Україні на основі формування виробничо-логістичних кластерів. Збірник наукових прачь УкрДУЗТ. 2015. Вип. 154. С. 98-103.

2. Компаниец В.В. Концептуальный анализ перспектив цифровизации экономики и железнодорожного транспорта. Вісник економіки транспорту і промисловості. 2018. № 62. С. 197-200.

3. Овчиннікова В.О., Торопова В.І. Розвиток підприємств залізничного транспорту України в умовах цифровізації. Вісник економіки транспорту і промисловості. 2019. № 68. С. 175-181.

4. Цифрова трансформація залізничного транспорту як фактор його інноваційного розвитку / І.В. Токмакова та ін. Вісник економіки транспорту і промисловості. 2019. № 68. С. 125-134.

5. Інтегрований звіт 2018: для інвесторів. $A T$ «Укрзалізниця» : офіційний вебсайт. URL : https://uz.gov.ua/about/ investors/issuer/ (дата звернення: 11.11.2019).

6. Цифровая железная дорога Европы - от ERTMS до искусственного интеллекта / О.Н. Покусаев и др. International Journal of Open Information Technologies. 2019. Vol. 7. № 7. C. 90-119.

7. Коваленко А.И. Проблематика исследований многосторонних платформ. Современная конкуренция. 2016. № 3(57). URL : https://cyberleninka.ru/article/n/problematika-issledovaniy-mnogostoronnih-platform (дата обращения: 18.02.2020).

\section{References:}

1. Dykan V.L., Korin M.V. Rozvytok vysokoshvydkisnoho rukhu v Ukraini na osnovi formuvannia vyrobnycholohistychnykh klasteriv. [Development of high-speed traffic in Ukraine on the basis of the formation of production and logistics clusters]. Zbirnyk naukovykh prats UkrDUZT, 2015, no. 154, pp. 98-103.

2. Kompaniec V.V. Konceptual'nyj analiz perspektiv cifrovizacii ekonomiki i zheleznodorozhnogo transporta. [Conceptual analysis of the prospects for digitalization of the economy and railway transport] Visnyk ekonomiky transportu i promyslovosti. 2018. no. 62, pp. 197-200.

3. Ovchynnikova V.O., Toropova V.I. Rozvytok pidpryiemstv zaliznychnoho transportu Ukrainy v umovakh tsyfrovizatsii. [Development of railway transport enterprises in Ukraine in the conditions of digitalization] Visnyk ekonomiky transportu $i$ promyslovosti. 2019. no. 68, pp.175-181.

4. Tokmakova I.V., Cherednychenko O.Iu., Voitov I.M., Palamarchuk Ya.S. Tsyfrova transformatsiia zaliznychnoho transportu yak faktor yoho innovatsiinoho rozvytku. [Digital transformation of railway transport as a factor of its innovative development] Visnyk ekonomiky transportu i promyslovosti. 2019. no. 68, pp. 125-134.

5. Intehrovanyi zvit 2018: dlia investoriv: [Integrated report 2018: for investors]. AT «Ukrzaliznytsia» : ofitsinyi sait. Available at: https://uz.gov.ua/about/investors/issuer/. (accessed: 11.11.2019).

6. Pokusaev O.N., Klimov A.A., Kupriyanovskiy V.P., Morhat P.M., Namiot D.E. Tsifrovaya zheleznaya doroga Evropyi ot ERTMS do iskusstvennogo intellekta [Europe's digital railway - from ERTMS to artificial intelligence]. International Journal of Open Information Technologies. 2019. T. 7, no. 7, pp. 90-119.

7. Kovalenko A.I. Problematika issledovaniy mnogostoronnih platform. [Problems of research on multilateral platforms]. Sovremennaya konkurentsiya. 2016. №3(57). Available at: https://cyberleninka.ru/article/n/problematika-issledovaniymnogostoronnih-platform (accessed:18.02.2020). 
Obruch Anna

Ukrainian State University of Railway Transport

\section{DEVELOPMENT OF RAILWAY TRANSPORT SERVICES BASED ON THE DEVELOPMENT OF DIGITAL PLATFORMS}

The article defines that increasing the competitiveness and ensuring sustainable development of railway transport enterprises requires a comprehensive improvement of the processes of implementing their services. Attention is focused on the discrepancy between the services of railway transport enterprises to the criteria of sustainable development in terms of technical condition, reliability and safety, logistics efficiency, resource saving and customer orientation. It is taken into account that the digital transformation of the economy has accelerated the spread of the platform business model, where the digital platform is a complex information system that provides the functions of interaction between market participants, it is open for use by customers and partners, including application developers, service providers and agents. It is determined that the digital platform allows economic agents to actively use the opportunities formed within the digital economy. They increase the efficiency of business processes, provide fast and reliable communications, create opportunities for the development of the sharing economy and the formation of new ways of creating value and mechanisms for interaction and exchange between economic agents, while reducing the role of geographical, temporal and other factors that affect socio-economic processes, institutions and phenomena. A multi-sided digital platform is defined as a progressive and promising form of business existence, since it is a free market model. It was found out that the development of multi-party platforms at railway transport enterprises allows them to implement the following functions: magnet; collector, analyzer and sources of market information; pimp (machmaker); intermediary-representative; guarantor-guarantor; innovation workshop; leader-innovator. It is concluded that for the successful operation of the digital platform must meet the following organizational conditions: the list of transport services, the pricing policy for these services and payment procedure; developed pricing and payment for services; developed work procedure all visitors, including clients and partners must register at the site and to obtain appropriate remedies; defined and technically implemented the interaction of information systems departments of enterprises of railway transport.

Key words: development, services, railway transport enterprises, digitalization, digital platform.

JEL classification: O33, D83. 